\title{
Effects of modified atmosphere packaging (MAP) and vaporized ethyl pyruvate (EP) treatment for the shelf life of 'Seolhyang' strawberries
}

\author{
Jinse Kim ${ }^{1,4 *}$, Jong Woo Park ${ }^{2}$, Seok Ho Park ${ }^{1}$, Dong Soo Choi ${ }^{1}$, Yong Hoon Kim ${ }^{1}$, \\ Soo Jang Lee ${ }^{1}$, Chun Wan Park ${ }^{1}$, Jung Soo Lee ${ }^{3}$, Byoung-Kwan Cho ${ }^{4}$ \\ ${ }^{1}$ Department of Agricultural Engineering, National Institute of Agricultural Sciences, RDA, Jeonju 54875, Korea \\ ${ }^{2}$ Department of Agricultural Biology, National Institute of Agricultural Sciences, RDA, Jeonju 55365, Korea \\ ${ }^{3}$ Postharvest Research Division, Horticultural and Herbal Science, RDA, Jeonju 55365, Korea \\ ${ }^{4}$ Department of Biosystems Machinery Engineering, College of Agricultural and Life Science, Chungnam National University, \\ Daejeon 34134, Korea
}

\section{딸기 ‘설향’ 품종의 MAP 및 ethyl pyruvate 처리의 유통기한 연장 효과 연구}

\author{
김진세 ${ }^{1,4 *} \cdot$ 박종우 $^{2} \cdot$ 박석호 $^{1} \cdot$ 최동수 $^{1} \cdot$ 김용훈 $^{1} \cdot$ 이수장 $^{1} \cdot$ 박천완 $^{1} \cdot$ 이정수 $^{3} \cdot$ 조병관 $^{4}$ \\ ${ }^{1}$ 농촌진흥청 국립농업과학원 농업공학부, ${ }^{2}$ 농촌진흥청 국립농업과학원 농업생물부, \\ ${ }^{3}$ 농촌진흥청 국립원예특작과학원 저장유통과, ${ }^{4}$ 충남대학교 바이오시스템공학과
}

\begin{abstract}
We have studied the technology to extend the storage period of 'Seolhyang' strawberies using modified atmosphere package (MAP) and ethyl pyruvate (EP) treatment for domestic distribution and export. The selected ripe strawberies harvested on December 28, 2016 at the Sancheong farmhouse were transported to the laboratory for $\mathbf{2} \mathrm{h}$ and tested. After a day's precooling at $4^{\circ} \mathrm{C}$, the strawberries were divided into seven experimental groups. These groups were control, active MAP using low density polyethylene (LDPE), active MAP using polyamide (PA), active MAP using PA with EP treatment, passive MAP using LDPE, passive MAP using PA and passive MAP using PA with EP treatment. Quality analysis was carried out every 4 days during the storage period of 16 days. During the storage period of 16 days, MAP decreased from $3.5 \%$ to less than $1.1 \%$ in weight loss ratio compared with control, and decreased from $36 \%$ to less than $7 \%$ in fungal incidence. In the case of fungi in the EP treatment group, hyphae did not grow on the outside of the strawbery but grew to the inside. This tendency was similar to that in the low oxygen and high carbon dioxide environment of the MAP, the mycelium of the fungus did not grow outside of the strawberry. Fungi are the biggest problem in the distribution and export of strawberries, and these results suggest that MAP alone could inhibit mold and increase shelf life.
\end{abstract}

Key words : modified atmosphere packaging, ethyl pyruvate, strawberry, quality change

\section{서 론}

농림축산식품부 수출통계에 따르면 딸기는 2016년 4.1 천톤, 34백만불을 수출하여 채소류 수출 중 파프리카, 토마

*Corresponding author. E-mail : ferroj@korea.kr Phone : 82-63-238-4127, Fax : 82-63-238-4105

Received 8 March 2017; Revised 23 April 2017; Accepted 1 May 2017.

Copyright (c) The Korean Society of Food Preservation. All rights reserved.
토에 이어 3위를 차지하고 있는 농산물이다. 한국농수산식 품유통공사의 2015년 유통실태조사에 따르면 딸기의 품종 별 정식비중은 '설향'의 경우 2013년 75.4\%에서 2014년 $78.4 \%$ 로 증가 추세이며, 대표적인 수출품종인 '매향'의 경 우 $2.3 \%$ 에서 $1.7 \%$ 로 감소 추세이다. '매향'은 수출을 위해 경남에서 2014년 7.2\% 재배되었지만, 이마저도 경남 산청 을 중심으로 '설향'으로의 수출 품종 전환이 이루어지고 있어서 점점 더 줄어들 예정이다. 하지만, '매향'에 비해 ‘설향’이 잿빛곰팡이병에 취약하다고 알려져 있으며(1), 딸 기 수출시 곰팡이 관련 클레임이 많이 발생하고 있어서 
‘설향'의 수출을 늘리기 위해서는 곰팡이를 억제할 수 있는 별도의 기술이 필요한 실정이다.

유통기한이 짧은 딸기의 특성상 그 유통기한을 늘리기 위한 연구가 다양하게 수행되어 왔다. 빠른 물러짐을 막기 위한 수확 전 칼슘-키토산 처리(2)와 고농도 $\mathrm{CO}_{2}$ 처리(3-5), 곰팡이 발생을 억제하기 위한 이산화염소수(6), ethyl pyruvate(EP) 훈증처리(7), 기체치환포장(8) 등의 연구가 있 었다. 하지만, 고농도 $\mathrm{CO}_{2}$ 처리 및 이산화염소수 처리의 경우 장시간 처리시 이취 와 탈색 등의 문제가 발생하므로 별도의 챔버에서 3 시간 정도만 처리해야하는 불편함이 있 다. 소포장 단위 기체조성포장(MAP, modified atmosphere package)의 경우 파렛트 단위로 쌓을 경우 필름이 중첩되어 내부에는 산소 없이 혐기성 호흡에 의해 변질되는 문제가 있기 때문에, 유통을 위해서는 파렛트 단위의 MAP 처리가 필요하며, 토마토의 경우 파렛트 단위 MAP 처리를 하였을 때 곰팡이 발생을 억제하여 유통기간을 1.5 배 연장한 연구 결과가 있다(9). EP 처리의 경우 기체상에서 식품유래 병원 균과 박테리아 증식을 억제한다는 연구가 이루어졌으며 $(10,11)$, 딸기의 경우 곰팡이를 억제한다는 연구 결과가 있 다(7). $\mathrm{EP}$ 는 미국 $\mathrm{FDA}$ 에서 식품첨가물로 허가가 되었고, 국내에서는 급성 폐손상 치료를 위해 사용되는(12) 등 인체 에 안전한 물질로 알려져 있다. 기존의 EP 처리는 큰 플라스 틱 용기 내에 소량의 농산물과 $\mathrm{EP}$ 원 액이 흡수된 거름종이 를 넣고 밀폐하는 방법으로 기체조성 변화를 고려하지 않았 다 $(7,10,11)$. 하지만, 농산물을 기밀 포장할 경우 호흡에 의 해 기체조성이 변화되기 때문에, active 및 passive MAP에 $\mathrm{EP}$ 처리를 추가할 경우 시너지 효과가 있는지 분석할 필요 가 있다.

수출 및 국내 유통에 보통 $250 \mathrm{~g}$ 혹은 $500 \mathrm{~g}$ 의 플라스틱 용기가 $2 \mathrm{~kg}$ 단위로 골판지 상자에 포장되며, 이러한 박스가 적재된 파렛트 단위로 운송된다. 이러한 종이박스포장을 파렛트 단위로 MAP 처리할 경우 필름 내부 결로는 박스의 강도를 약하게 만들어서 무너지게 만드는 문제가 있으며, 수분투과도가 높은 polyamide 6(PA), polylactic acid(PLA) 필름을 이용할 경우 MAP 내부의 결로를 줄일 수 있었다는 연구결과가 있지만(13), 일반적인 low density polyethylene(LDPE) 필름을 이용할 경우와 비교하여 감모 율이 어떻게 달라지는지 비교할 필요가 있다. 본 연구에서 는 수분투과도가 높은 PA 필름과 낮은 LDPE 필름을 이용 한 $\mathrm{MAP}$ 의 감모율 및 곰팡이 발생률 차이, $\mathrm{EP}$ 훈증 처리구와 미처리구의 곰팡이 발생률 차이를 분석하고자 하였고, $\mathrm{MAP}$ 의 경우 active와 passive 기체조성을 하여 그 효과 차이 를 알아보고자 하였다. 또한 상기 여섯 가지 처리구과 저온 저장한 대조구와의 품질차이를 비교하여, 경제적으로 곰팡 이를 억제할 수 있는 딸기의 포장방식을 제시하고, 향후 파렛트 단위 MAP에 활용하고자 한다.

\section{재료 및 방법}

실험재료

본 실험에 사용된 시료는 경남 산청의 딸기수출 농업회 사법인 (주조이팜으로부터 2016년 12월28일 착색도 85\%정 도인 상태를 수확한 '설향' 딸기(Fragaria ×ananassa Duch.) $2 \mathrm{~kg}$ 단위 58 박스를 무진동차량을 이용하여 운송거리 2 시간 인 전북 전주에 위치한 실험실로 납품받아 사용하였다.

\section{$\mathrm{MAP}$ 및 $\mathrm{EP}$ 처리 저장환경}

$4^{\circ} \mathrm{C}$ 저온저장고에서 24 시간 예냉된 딸기를 4 일 단위로 16 일까지 분석하기 위해 $2 \mathrm{~kg}$ 박스 두 개를 단위로 하여 포장하였다(Fig. 1). 딸기의 MA저장 중 이취는 혐기성호흡 에 의해 생기는데, $\mathrm{O}_{2}$ 를 $2 \mathrm{kPa}$ 보다 높은 상태로 유지되도록 하고 $\mathrm{CO}_{2}$ 를 0에서 $20 \mathrm{kPa}$ 상태로 유지할 경우 혐기성 호흡 이 발생하지 않으며, $\mathrm{O}_{2} 5 \mathrm{kPa}$ 이하, $\mathrm{CO}_{2} 20 \mathrm{kPa}$ 기체조성에 서 호흡속도를 현저히 낮출 수 있기 때문에(14), 본 실험의 $\mathrm{MAP}$ 최종 기체농도는 $\mathrm{O}_{2} 2-5 \%, \mathrm{CO}_{2} 15-20 \%$ 를 목표로 하였 다. Active MA의 초기 가스 치환 농도는 $5-10 \% \mathrm{O}_{2}, 5-8 \%$ $\mathrm{CO}_{2}, 84-88 \% \mathrm{~N}_{2}$ 가 되도록 필름내부의 기체농도를 기체혼 합기(MAP Mix 9001 ME, PBI Dansenser, Ringsted, Denmark)와 휴대용 가스센서(CheckPoint, $0-100 \% \mathrm{O}_{2} / \mathrm{CO}_{2}$, relative accuracy $3 \%$, resolution $0.1 \%$, Dansensor, Ringsted, Denmark)를 이용하여 조성하였다. 결로 방지를 위해 수분 투과도가 높은 필름을 사용할 경우 감모율에 대한 영향을 확인하고자 일반적인 LDPE 필름(두께 $0.1 \mathrm{~mm}$ )과 이보다 수분투과도가 약 100배 높은(15) PA 필름(두께 $0.015 \mathrm{~mm}$ ) 을 이용하여 비교 실험하였다. 외국의 경우 $\mathrm{EP}$ 처리를 밀폐

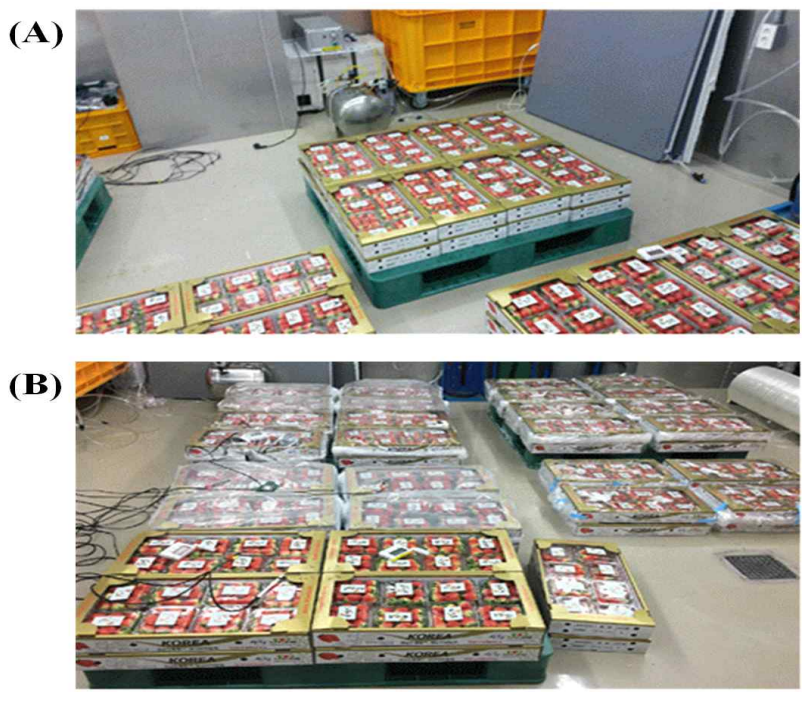

Fig. 1. Pre-cooled strawberries at $4{ }^{\circ} \mathrm{C}$ (A) and strawberries stored in seven ways (B) such as the control, active MAP using LDPE, active MAP using PA, active MAP using PA with EP treatment, passive MAP using LDPE, passive MAP using PA and passive MAP using PA with EP treatment. 
박스에서 실험하였는데(7), 박스 내부의 기체조성에 대한 언급이 없어서, 본 실험에서는 PA 필름을 이용한 최적의 $\mathrm{MAP}$ 와 이러한 MAP 내부에 EP 훈증처리를 할 경우를 비교 하여 곰팡이 생장을 더욱 억제할 수 있는지 비교하였다. $\mathrm{EP}$ 처리의 경우 딸기 $2 \mathrm{~kg}$ 수출용박스 2 개를 포장한 필름(약 $20 \mathrm{~L}$ air) 내부에 위치한 실험용 티슈에 $\mathrm{EP} 4 \mathrm{~mL}$ 를 주사기로 흡수시켜서 자연적으로 증발하도록 처리하였다. 이러한 처 리량은 Bozkurt 등(7)의 연구결과에서 곰팡이 억제효과가 있는 $192 \mu \mathrm{L} / \mathrm{L}$ air와 유사한 $200 \mu \mathrm{L} / \mathrm{L}$ air 수준이다. 초기에 기체농도를 변화시키지 않는 passive MA 방법은 active MA 보다 포장이 쉽지만, 저장초기부터 곰팡이를 억제하기는 어렵다. Active $\mathrm{MA}$ 와 비교하여 passive $\mathrm{MA}$ 에서의 곰팡이 발생정도의 차이를 비교하고자 $\mathrm{LDPE}$ 와 $\mathrm{PA}$ 필름으로 포장 하여 실험하였고, passive MA환경에서 $\mathrm{EP}$ 처리를 통한 곰팡 이 억제효과에 차이가 있는지를 확인하고자 하였다. passive $\mathrm{MA}$ 의 초기 기체조성은 대기의 기체조성인 $20.93 \%$ $\mathrm{O}_{2}, 0.03 \% \mathrm{CO}_{2}, 78.1 \% \mathrm{~N}_{2}, 0.94 \% \mathrm{Ar}$ 이며, 저장기간 중 딸기 의 호흡에 의해 산소 농도가 줄어들고, 이산화탄소 농도가 증가하도록 하였다.

호흡속도가 높은 채소에 속하는 딸기의 경우 필름에 천 공을 하지 않으면 필름의 기체투과도가 딸기의 호흡속도를 따라가지 못해서 내부의 산소가 고갈되고 혐기성 호흡을 하게 된다. 특히 기체투과도가 낮은 PA 필름을 이용할 경우 천공은 필수적이다. 이러한 천공면적을 기존 연구의 모델 링 공식들을 활용하여 계산할 수 있지만, 호흡속도와 천공 을 통한 산소투과도는 온도와 기압, MAP 내부의 산소 및 이산화탄소의 농도에 영향을 받는 복잡한 상관관계 때문에 매우 복잡한 계산이 필요하며, 모델링 공식도 다양하기 때 문에 모델링 종류별로 별도의 관계식이 생긴다 $(16,17)$. 따 라서 본 연구에서는 이러한 관계식들을 저장조건에 비추어 근사적으로 최소화된 비례식을 구하고, 그 비례상수는 실 험적인 측정값을 이용하여 계산하려고 한다.

딸기의 호흡속도에 대한 모델링 공식 중 일정 온도조건 에서의 호흡속도 공식은 다음과 같다(14).

$$
\begin{aligned}
& V_{\max } C_{O_{2}} \\
& \left(K+C_{O_{2}}\right)
\end{aligned}
$$

$R_{O_{2}}$ 는 딸기의 산소소비율이며, $V_{\max }$ 는 산소를 고압 고 순도로 공급했을 때 얻을 수 있는 최대의 호흡속도, $K_{m}$ 은 Michaelis-Menten 상수, $C_{O_{2}}$ 는 산소농도이다. 일반적으로 MAP 내부의 산소 농도를 일정하게 유지하는 것이 목적이 며 본 연구에서는 $5 \%$ 인근을 유지하는 것이 목표이므로 $C_{O_{2}}=5 \%$ 인근의 경우 이 호흡속도는 상수가 되며, 딸기 $M \mathrm{~kg}$ 을 저장할 경우 산소 소모율은 저장 중량에 비례하게 된다.
필름에 천공이 있을 경우 기체치환율은 Graham's law를 바탕으로 구멍을 통과할 확률(18)과 Fick's first law를 바탕 으로 한 필름 자체의 기체투과 확률(19)의 합에 의해 다음과 같이 근사적으로 나타낼 수 있다.

$$
\text { as }\left(\begin{array}{c}
c_{1} A_{\text {hole }}+c_{2} \\
M_{\text {molar }}
\end{array}\right.
$$

$J_{g a s}$ 는 기체치환율이며, $c_{1}, c_{2}$ 는 비례상수, $A_{h o l e}$ 는 천 공면적, $M_{m o l a r}$ 은 기체의 분자량, $A_{f i l m}$ 는 필름의 포장면 적, $T$ 는 필름두께, $C_{\text {gas Outside }}, C_{\text {gas Inside }}$ 는 $\mathrm{MAP}$ 외부 및 내부의 기체농도이다. PA 필름의 기체투과도는 매우 낮은 편이며(15), 이 경우 필름 자체의 투과도를 근사적으로 무시 할 수 있다. 또한 포장 내부의 목표 농도와 외부의 기체농도 차이는 상수이므로 다음과 같이 근사적으로 나타낼 수 있 다.

$$
J_{\text {gas }}=c_{1}^{\prime} \quad \begin{aligned}
& A_{\text {hole }} \\
& M_{\text {molar }}
\end{aligned}=c_{1}^{\prime \prime} A_{\text {hole }}
$$

딸기 $M \mathrm{~kg}$ 에 대한 산소소비율과 천공에 의한 산소투과 율이 같다고 할 경우 다음과 같이 간략화 할 수 있다.

$$
M \quad R_{O_{2}}=c_{1}^{\prime \prime} A_{\text {hole }}
$$

즉, 천공면적 $A_{h o l e}$ 은 저장하는 딸기의 중량 $\mathrm{M}$ 과 저장온 도에 따른 산소소비량 $R_{O_{2}}$ 과 비례관계를 갖는다.

$$
A_{\text {hole }}=c \times M \times R_{O_{2}}
$$

산소 소비와 이산화탄소 생성은 그 분자량의 비율인 $R_{\mathrm{O}_{2}}={ }_{44}^{32} R_{\mathrm{CO}_{2}}$ 의 비례관계가 있으므로, 천공면적은 이산 화탄소 생성 비율에 대한 비례식으로 다음과 같이 바꿀 수 있다.

$$
A_{\text {hole }}=c^{\prime} \times M[k g] \times R_{C O}\left[m g C O_{2} / k g \quad h\right]
$$

$5 \% \mathrm{O}_{2}$ 조건에서의 호흡속도는 일반적인 대기조건에서 의 호흡속도보다 느리겠지만, $(\mathrm{A})$ 의 비례식을 통해 그 일반 적인 호흡속도와 비례할 것이며, 작목의 온도별 호흡속도 를 참고한다면(20), 하나의 작목에 대해서 구한 값을 일반화 할 수 있다고 생각하였다. 본 연구에서는 토마토를 기준으 로 천공 개수를 늘리며 실험적으로 구한 값인 $c^{\prime} \quad 6110$ 와 딸기의 $4^{\circ} \mathrm{C}$ 호흡속도인 $20 \mathrm{mgCO} / \mathrm{kg} \quad h$ 을 기준으로 
하여 다음과 같이 천공에 필요한 구멍의 지름을 산출하였 다.

$$
2 \quad \begin{gathered}
6110 \times 4 k g \times 20 \\
\pi
\end{gathered}=789[\mu m]
$$

실험적으로는 지름 $7 \mathrm{~mm}$ 의 구멍을 천공하였고, 계산된 값보다 작은 천공을 하였으므로, MAP내부의 기체조성은 대략 2-5\% $\mathrm{O}_{2}$ 에서 안정화될 것이라 예상하였다.

저장기간동안 MAP내부의 기체조성을 휴대용 가스센서 (CheckPoint, 0-100\% $\mathrm{O}_{2} / \mathrm{CO}_{2}$, relative accuracy 3\%, resolution $0.1 \%$, Dansensor, Ringsted, Denmark)를 이용하여 1 일간격 으로 측정하였으며, 내부의 온습도를 유선온습도센서 (EK-H4+SHT75, $-40-125^{\circ} \mathrm{C}, 0-100 \%$, temperature accuracy $0.3^{\circ} \mathrm{C}$, humidity accuracy $1.8 \%$, Sensirion, Staefa, Switzerland) 와 무선온습도센서(TR-73U, 750 to $1,100 \mathrm{hPa}, 0-50^{\circ} \mathrm{C}$, $10-95 \%$ RH, T\&D, Nagano, Japan)를 이용하여 10 분간격으 로 측정하였다.

\section{감모율 및 부패율, 곰팡이 분석}

예냉이 끝난 시료의 MAP 처리전에 각각의 실험구 단위 로 $250 \mathrm{~g}$ 플라스틱 팩 단위의 딸기 중량을 측정하고 4,8 , 12,16 일차에 각각의 플라스틱 팩 단위의 중량을 다시 측정 하여 아래의 식에 따라 개별단위의 감모율을 산출하였다. 모든 중량 측정은 딸기 표면 결로에 의한 측정오류를 없애 고자 저장중인 $4^{\circ} \mathrm{C}$ 저온저장고 안에서 측정하였다. 부패율 은 각각의 플라스틱 팩 단위로 딸기 개수 및 곰팡이가 발생 한 개수를 통해 산출하여 각각의 실험구 $250 \mathrm{~g}$ 단위 16 팩에 대한 부패율을 부패개수/총개수의 백분율로 나타내었다.

Weight loss rate $(\%)=\left\{\left(\mathrm{W}_{1}-\mathrm{W}_{2}\right) / \mathrm{W}_{1}\right\} \times 100$

$\left(\mathrm{W}_{1}=\right.$ 저장 전 중량, $\mathrm{W}_{2}=$ 저장 후 중량)

저장 중 변색된 딸기가 병원균에 의한 것인지 곰팡이에 의한 것인지를 확인하고자 $-80^{\circ} \mathrm{C}$ 초저온 냉동고(DFC-200, Operon, Gimpo, Korea)에 얼려 두었던 딸기를 냉동절편기 (CM1520, Leica, Wetzlar, Germany)를 이용하여 $20 \mu \mathrm{m}$ 두께 의 시편을 제작하고 현미경(DM750, Leica, Wetzlar, Germany)으로 관찰하였다. 현미경에서 관찰된 균사체가 어떤 곰팡이인지 확인하고자 $25^{\circ} \mathrm{C}$ 인큐베이터에서 $\mathrm{PDA}$ (potato dextrose agar) 배지에 7일간 배양하여 콜로니 및 포자의 형상을 확인하였다.

\section{색도 및 경도 분석}

각 실험구 별로 플라스틱 팩에서 임의로 선정된 2 개의 딸기 총 32 개에 대해 색이 붉은색으로 착색된 과일의 중심 부위를 색차계(CR-400, Konica Minolta, Tokyo, Japan)을
이용 Hunter L, a, b 값을 3 반복으로 총 96번 측정하였다. 색도는 명도(lightness)를 나타내는 $\mathrm{L}$ 값, 적색도(redness)를 나타내는 $\mathrm{a}$ 값과 황색도(yellowness)를 나타내는 $\mathrm{b}$ 값으로 나타내었다.

딸기의 경도도 마찬가지로 각각의 플라스틱 팩에서 임의 로 선정된 2 개의 딸기에 대해 세로방향으로 $1 / 2$ 절단한 뒤 절단면을 위로하여 시료의 중간부분을 물성분석기 (TA-XT2 texture analyser, Stable Micro System Ltd., Godalming, UK)로 측정하였다. 측정 탐침은 지름 $3 \mathrm{~mm}$ probe를 사용하였으며, $0.3 \mathrm{~mm} / \mathrm{sec}$ 의 속도로 $5 \mathrm{~mm}$ 까지의 최대 압축 강도를 측정하여 $\mathrm{N}$ 단위로 나타내었다. 경도는 실험구 별로 총 32 개의 샘플에 대해 측정하였다.

\section{가용성 고형분 및 적정산도 분석}

실험구 별 각각의 플라스틱 팩에서 임의로 $\mathbf{5}$ 개씩의 딸기 를 선정하여 착즙망(Whirl-pak B01248WA, Nasco, Fort Atkinson, WI, USA)으로 착즙한 추출액에 대하여 디지털 굴절 당도계(RX-5000a, Atago Co., Tokyo, Japan)를 이용하 여 당도를 측정하고 ${ }^{\circ} \mathrm{Brix}$ 단위로 나타내었다. 실험구별 16 개의 플라스틱 팩에서 착즙한 16 개의 샘플에 대해 당도 측정을 하였다. 또한 딸기 추출액 $5 \mathrm{~mL}$ 을 취하여 $45 \mathrm{~mL}$ 의 증류슈에 희석한 후 자동 적정기(TitroLine $500, \mathrm{Si}$ Analytics, Mainz, Germany)를 이용하여 $\mathrm{pH}$ 8.3이 될 때까지 $0.1 \mathrm{~N} \mathrm{NaOH}$ 용액으로 적정하였다. 각 실험구당 16 개의 시료에 대하여 측정한 평균값을 citric acid로 환산하여 나타 내었다.

\section{통계분석}

모든 분석결과는 실험구당 3 회 반복이상 실험한 결과로 부터 평균값과 표준편차로 나타내었으며 통계분석은 IBM SPSS Statistics(24, IBM Corp., Armonk, NY, USA)를 이용하 여 ANOVA test와 Duncan's multiple range test를 통해서 시료 간 유의적 차이 $(\mathrm{p}<0.05)$ 를 검정하였다.

\section{결과 및 고찰}

\section{딸기의 저장 환경변화}

딸기의 저장기간 중 저장고 내부와 MAP 필름 내부의 온습도를 무선 및 유선 온습도 센서를 이용하여 측정하였다 (Fig. 2). 무선 온습도 센서는 상층 박스의 상부에 위치하도 록 하고, 유선 온습도 센서는 상층 박스의 아랫면에 위치하 도록 하여 MAP 표면과 중심부의 온습도를 측정하였다. 유선 온습도 센서의 경우 전력계통 전환에 의한 두 번의 소프트웨어 다운으로 인해 저장 1-3일차와 11-14일차 데이 터를 소실하였지만, 저장 4-10일차 PA를 이용한 MAP의 외부와 내부 온습도 최대값과 최소값 편차를 비교해 보면, 
저장고 내부는 $4.4^{\circ} \mathrm{C} 28 \%, \mathrm{MAP}$ 표면은 $2.7^{\circ} \mathrm{C} 9 \%, \mathrm{MAP}$ 중심부는 $0.6^{\circ} \mathrm{C} 2.5 \%$ 로 측정되었다(Fig. 2). 이것은 저장고 내부의 온습도가 크게 변하여도, MAP 내부는 그 편차가 완화되어서, 농산물을 보다 일정한 환경에서 저장하는 효 과가 있다. Fig. 2B에 따르면 수분투과도가 상대적으로 높 은 PA 필름을 이용한 MAP의 경우 4-10일차의 상대습도가
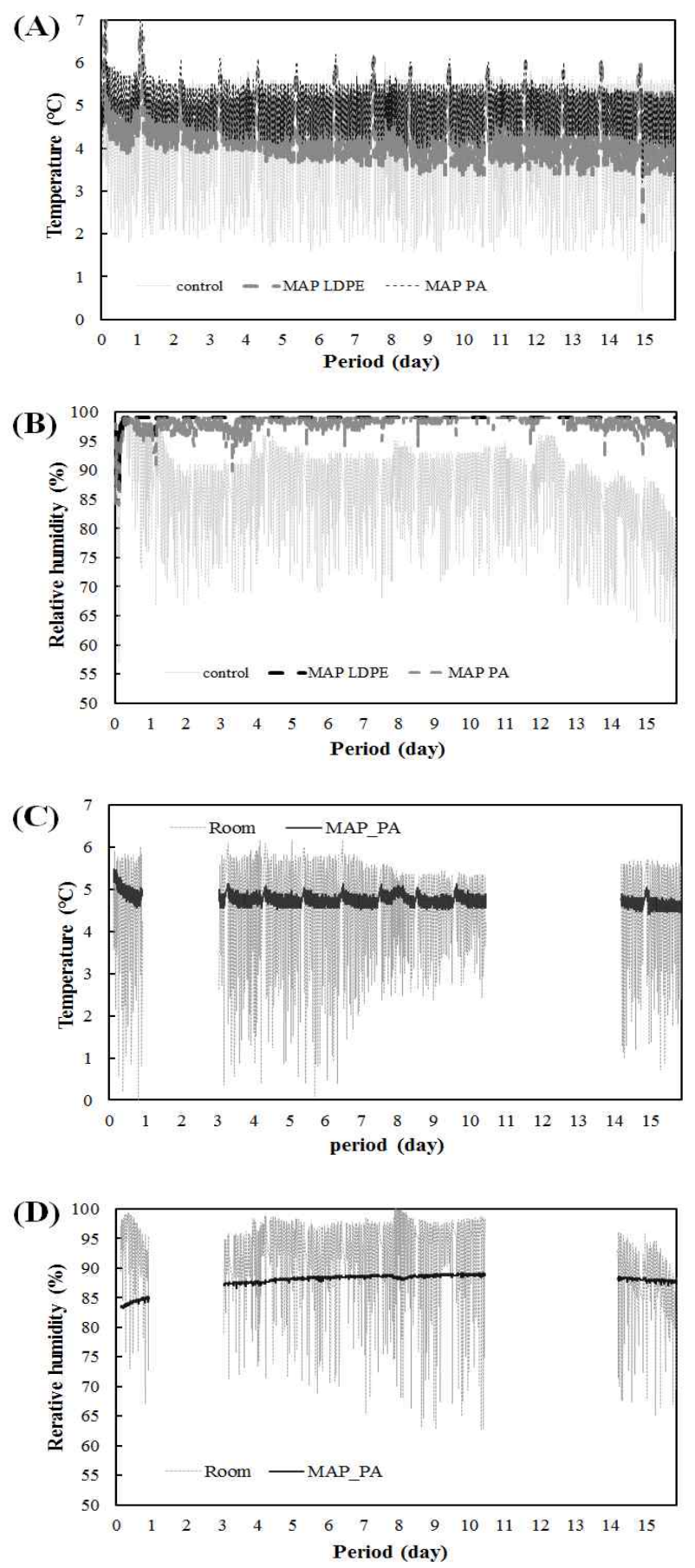

Fig. 2. Temperature and humidity at the upper part of the MAP measured with wireless sensors (A and B), and the temperature and humidity at the center measured by wire sensors (C and D).
90-99\%의 9\% 편차를 보이나, 수분투과도가 낮은 $\mathrm{LDPE}$ 의 경우 $99 \%$ 로 포화되어 변동이 없었으며, Fig. 3에서도 LDPE 필름의 경우 결로 현상이 나타났으나 $\mathrm{PA}$ 필름의 경우 나타 나지 않았다. 이것은 $\mathrm{Kim}$ 등(13)의 연구에서 PA와 PLA 필름을 사용할 경우 결로 현상을 억제할 수 있다는 연구결 과와 일치한다.

저장 중 MAP 내부의 기체조성 변화는 Fig. 4와 같이 나타났다. 기체투과도가 낮은 PA 필름을 이용한 active 및 passive $\mathrm{MAP}$ 의 경우 16 일 저장했을 때는 $\mathrm{CO}_{2}$ 농도가 $20 \%$ 까 지 도달하였으나, $\mathrm{LDPE}$ 필름을 사용할 경우에는 $15 \%$ 까지 도달하였다. 이것은 $\mathrm{LDPE}$ 필름의 기체투과도가 $\mathrm{PA}$ 필름과 비교하여 300 배 정도 높으며(15), 계산식 $(\mathrm{B})$ 에서 필름자체 기체투과도를 무시하고 근사적으로 계산하였기 때문에 나 타난 편차이다. 하지만, 최종 가스농도 목표 값인 $\mathrm{O}_{2} 2-5 \%$, $\mathrm{CO}_{2} 15-20 \%$ 에 해당하기 때문에 적절하게 포장되었다고 생각할 수 있다. $\mathrm{PA}$ 필름에 $\mathrm{EP}$ 처리를 한 경우 기체농도는 Fig. 4B와 $4 \mathrm{C}$ 처럼 비슷하게 변해야 하나, Fig. $4 \mathrm{~F}$ 가 $4 \mathrm{E}$ 와 다르게 변한 것은 $4 \mathrm{~F}$ 에 넣은 실험용 티슈가 $\mathrm{PA}$ 필름에 접촉하고 있었으며, $\mathrm{EP}$ 의 유기용매와 같은 특성이 필름을 변질시켜서 기체투과도를 높였기 때문이라 할 수 있다.

(A)

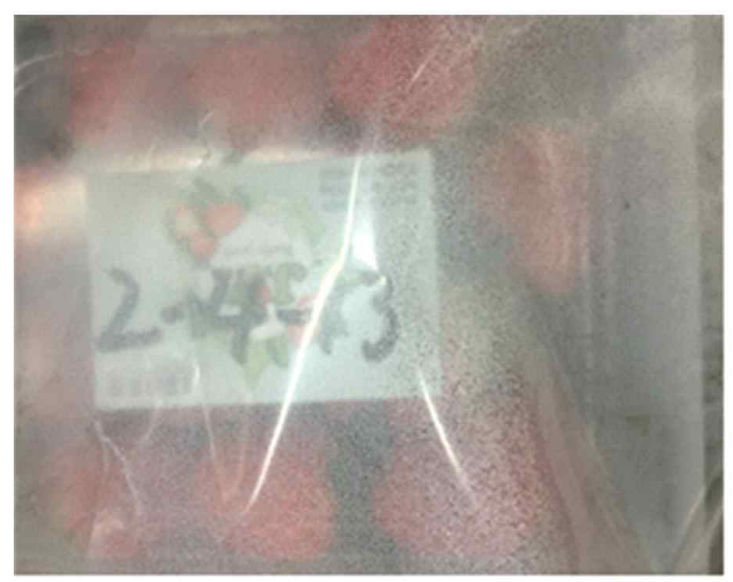

(B)

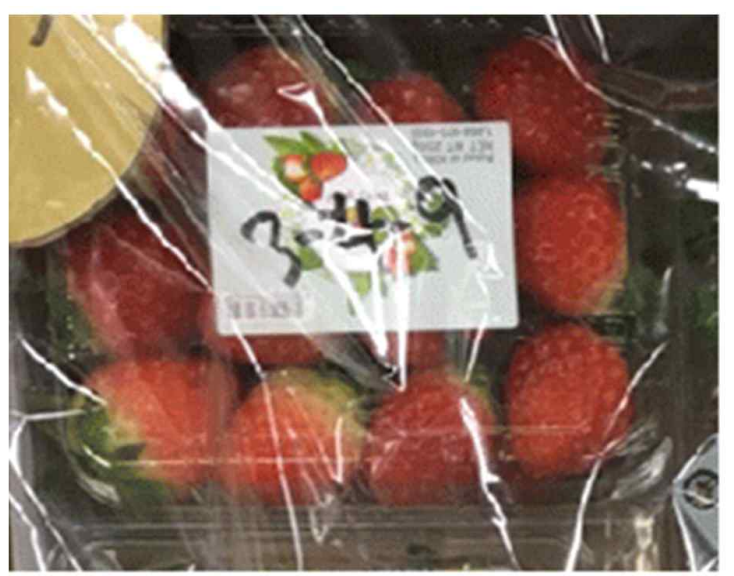

Fig. 3. Water condensation of MAP using LDPE and no condensation of MAP using PA film (B). 

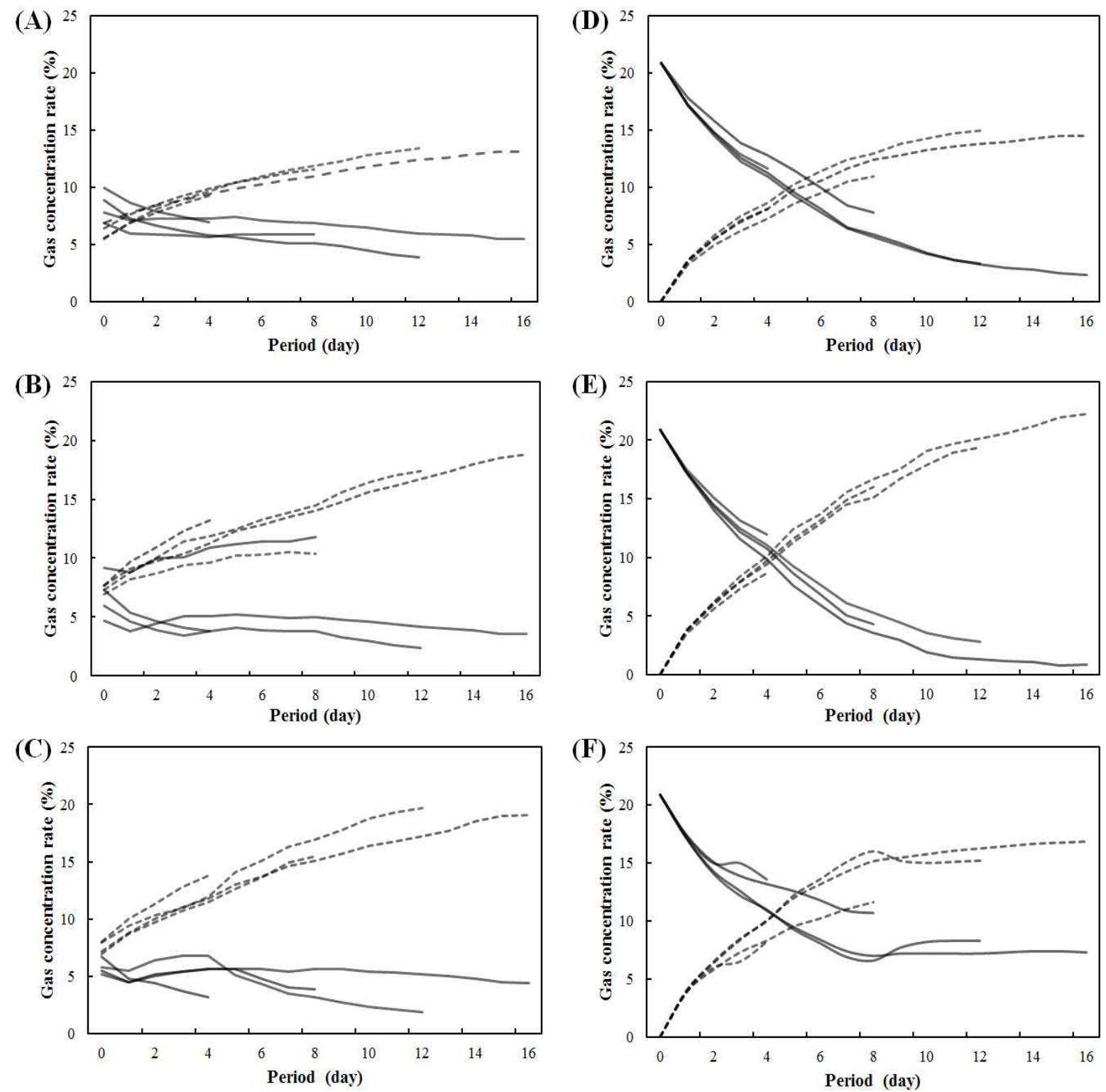

Fig. 4. Changes in gas concentration in MA packages stored for 4, 8, 12, and 16 days such as active MAP using LDPE (A), active MAP using PA (B), active MAP using PA with EP treatment (C), passive MAP using LDPE (D), passive MAP using PA (E) and passive MAP using PA with EP treatment $(\mathrm{F})$. and PA $(\mathrm{B} / \mathrm{E})$ film, and active/passive MAP using PA with EP treatment $(\mathrm{C} / \mathrm{F})$. The straight line means oxygen concentration, and the dotted line means carbon dioxide concentration.

\section{MAP 저장에 따른 부패율 및 감모율 변화}

딸기의 부패율은 저온저장의 경우 8 일차 $1.1 \%$ 에서 12 일 차에 $12 \%, 16$ 일차에 $36 \%$ 로 확연하게 증가하였으며, 곰팡 이가 주변의 딸기에 옮아가는 형태로 나타났다(Fig. 5A). 하지만, $\mathrm{MAP}$ 와 $\mathrm{EP}$ 처리한 $\mathrm{MAP}$ 의 경우 외부로 나타난 균사 체 없이 색이 변하며 물러지는 형태로의 부패가 나타났으며 (Fig. 5B), 동결절편기를 이용하여 그 내부를 $20 \mu \mathrm{m}$ 두께로 절단한 시편에 대해 현미경 관찰시 균사가 세포에 침투해서 자라고 있음을 확인하였고(Fig. 5C), 이러한 균사를 PDA 배지에 배양한 결과 Fig. 5D와 같은 포자를 형성하였다. 대조구에서 발생한 곰팡이를 관찰하였을 때 Fig. $5 \mathrm{D}$ 와 같은
포자가 관찰되었으며, 이러한 포자 형태는 잿빛곰팡이병원 균인 Botrytis cinerea인 것으로 확인되었다(21). B. cinerea 의 경우 $-2-5^{\circ} \mathrm{C}, \mathrm{pH} 2-8, \mathrm{O}_{2} 1 \%$ 이상에서 자랄 수 있다고 하지만(21), 호기성 미생물이기 때문에 $\mathrm{O}_{2} 5 \%$ 이하, $\mathrm{CO}_{2} 15 \%$ 이상의 MAP 환경에서는 딸기 외부로의 균사 성장 이 억제되고 내부로만 자란 것으로 생각된다. $\mathrm{EP}$ 처리의 경우에도 딸기 내부의 균사 성장을 억제하지는 못했으며, $\mathrm{MAP}$ 기체조성과 $\mathrm{EP}$ 처리가 동일하게 노출된 균사의 성장 을 억제하는 효과만 있음을 확인하였다.

잿빛곰팡이병은 개화기와 성숙과에 전염이 잘되고(1),선 별장에서도 잿빛곰팡이병이 전염될 수 있다는 연구결과가 
(A)

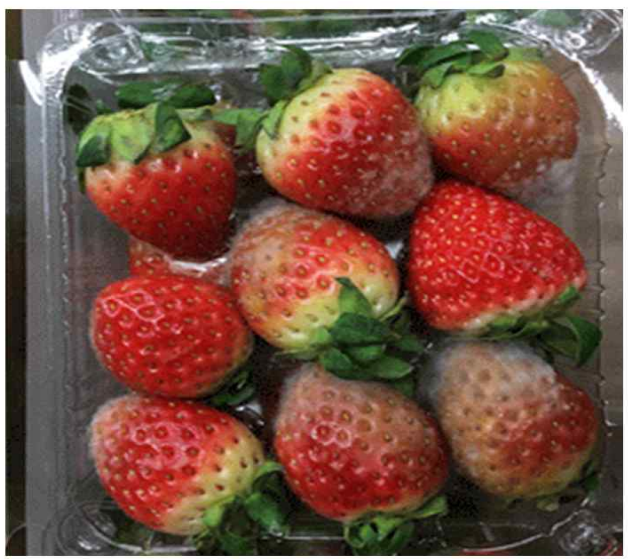

(C)

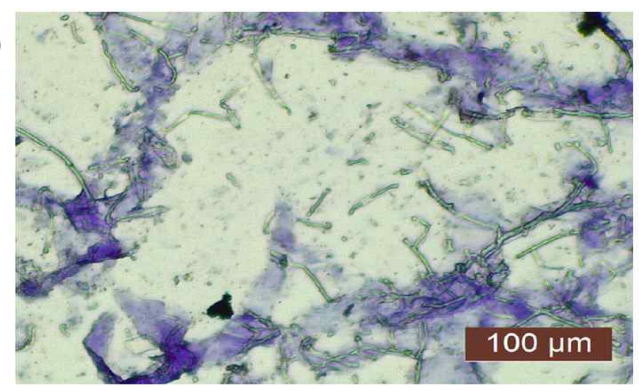

(B)

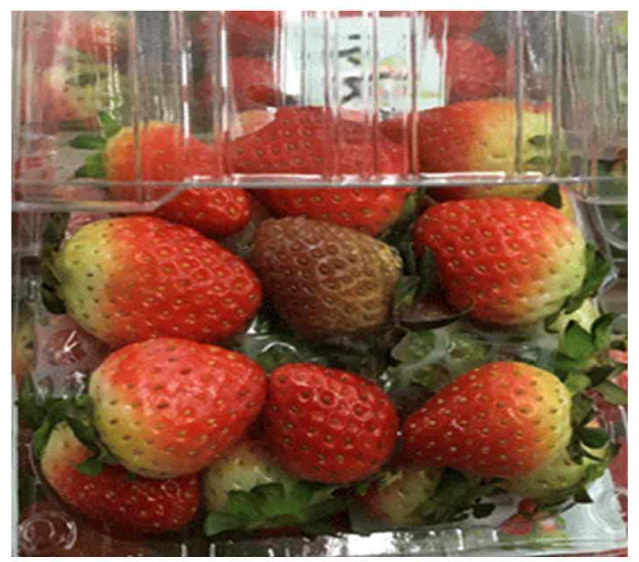

(D)

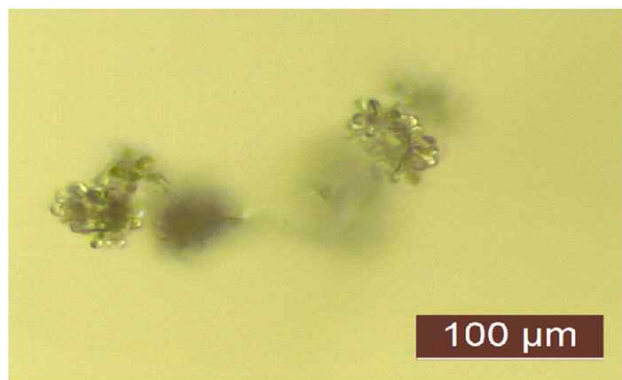

Fig. 5. Fungal growth patterns of low-temperature stored strawberries (A) and MA-packaged strawberries (B), and microscopic images of an inner specimen cut with a cryomicrotome (C) and cultured spores (D) from infected strawberry during MAP storage.

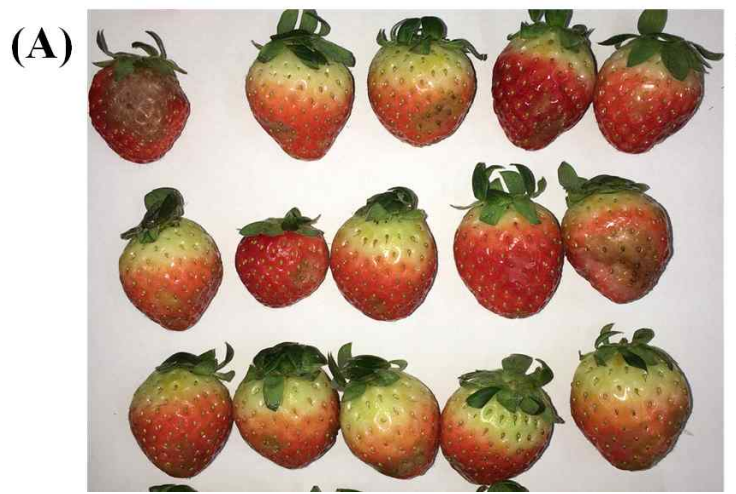

(B)

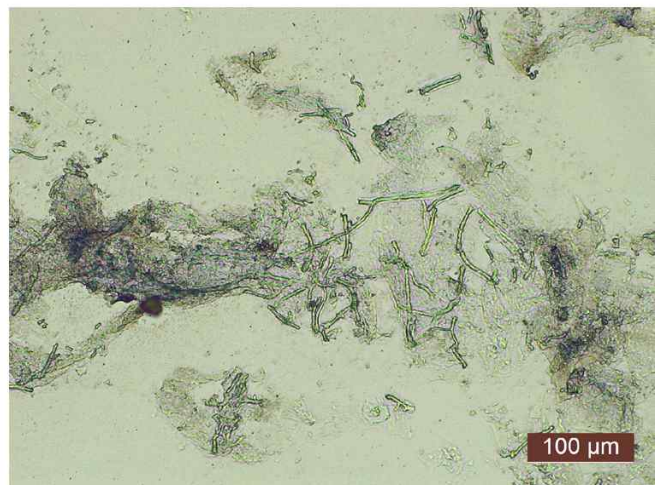

Fig. 6. Fungal growth due to handprint of strawberry surface during MAP storage using LEPE film (A), and the microscopic image of a specimen inside a handprint cut with a cryomicrotome (B).

있으며(22), LDPE MAP 저장 16 일차 $250 \mathrm{~g} 16$ 개 팩 중 한 개의 팩에서 19 개의 딸기 중 13 개가 집중적으로 손자국 형태의 변색이 나타났고(Fig. 6A), 그 손자국 내부를 조직을 동결절편기로 시편을 만들어 현미경 관찰을 한 결과 $B$. cinerea 균사가 관찰되었다(Fig 6B). 따라서 이러한 곰팡이 는 수확이나 선별시 발생한 손자국으로부터 시작되었다고 판단되어지며, 수확과 선별시 장갑위에 1 회용 비닐장갑을 착용하여 수확하는 딸기가 B cinerea 포자에 오염되지 않도 록 주의한다면, MAP 처리만으로도 곰팡이 발생을 억제할 것으로 판단된다.
저온저장과 각각의 $\mathrm{MAP}$ 에 의한 저장기간에 따른 감모 율 및 부패율 변화는 Fig. 7와 같다. 딸기의 감모율의 경우 저온저장의의 16 일차 감모율이 $3.5 \%$ 인데 반해 각각의 MAP 16일차 감모율은 0.8-1\% 수준으로 낮게 나타났다. 수분투과도가 낮은 LDPE 필름의 경우 PA 필름을 사용할 경우보다 평균적으로 약간 낮은 감모율을 보였으나 통계적 으로 차이는 없는 수준이었다. 포장단위가 커질 경우 중량 대비 필름 표면적의 비율이 작아지기 때문에 필름 차이에 의한 감모율 차이는 더욱 줄어들 것이라 생각된다. 
(A)
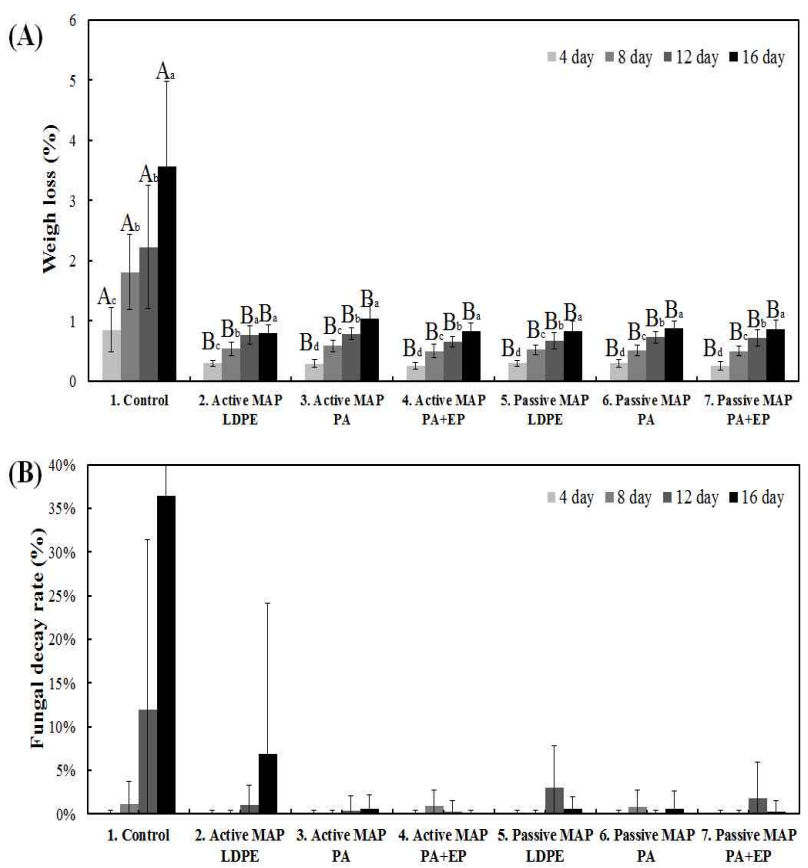

Fig. 7. The weight loss rate (A) and mold loss rate (B) for each experimental group.

The bar graph means the mean value and the error bar means the standard deviation. When the alphabetic capital letters in graph A are different, it means that there is a meaningful difference according to the kind of storage in the same storage day, and lower case letters are displayed differently when there is a difference in storage period within the same storage method. The determination of the difference was calculated by Duncan's multiple range test of significance level 0.05 .

\section{MAP 저장에 따른 색도 및 경도 변화}

딸기의 색은 성숙도를 판단하는 지표로서 숙성에 따라 하얀색에서 적색으로 변화한다. 각각의 실험구에 대한 시 간에 따른 색도 변화는 Fig. 7과 같다. 저장 중 숙성이 진행될 경 우 $\mathrm{L}$ 값은 줄어들고, $\mathrm{a}$ 값은 증가하며, $\mathrm{b}$ 값은 감소하는 경향을 나타낼 것이고 이러한 경향성은 각각의 실험구에서 대체적으로 비슷하게 나타났다. 본 실험에서 사용된 딸기 는 $85 \%$ 숙도를 수작업으로 선별된 것이기 때문에, 선별자 마다 차이가 있을 수 있어서 일부 경향성에서 벗어난 값들 이 측정되었지만, 적색도 a 값을 보면 active MAP의 경우가 passive MAP나 저온저장 대비 대체로 낮은 값을 유지하여 숙성을 지연하는 효과가 있다고 판단된다.

저장 중 경도변화를 측정한 것은 Fig. 8과 같다. 딸기를 $\mathrm{CO}_{2}$ 농도 $15 \%$ 로 42 시간을 처리할 경우 품종별로 차이가 있지만 경도가 평균적으로 $29.5 \%$ 증가하였다는 연구를 고 려할 때(3), $\mathrm{CO}_{2}$ 농도 10-20\% 구간에서 일주일 이상 MAP 저장을 하였기 때문에 대조구 대비 경도가 높게 유지될 것이라 예상하였으나, MAP 저장 딸기의 경도가 저온저장 딸기보다 높게 유지되는 경향성은 나타나지 않았다. Kim 등(5)의 연구에 따르면 $70 \%$ 숙도로 수확된 지 1 일 이내에 $\mathrm{CO}_{2}$ 처리시 경도 향상 효과가 나타난다는 연구결과가 있는 데, 본 실험에서는 $85 \%$ 숙도로 선별된 딸기를 배송 받아서
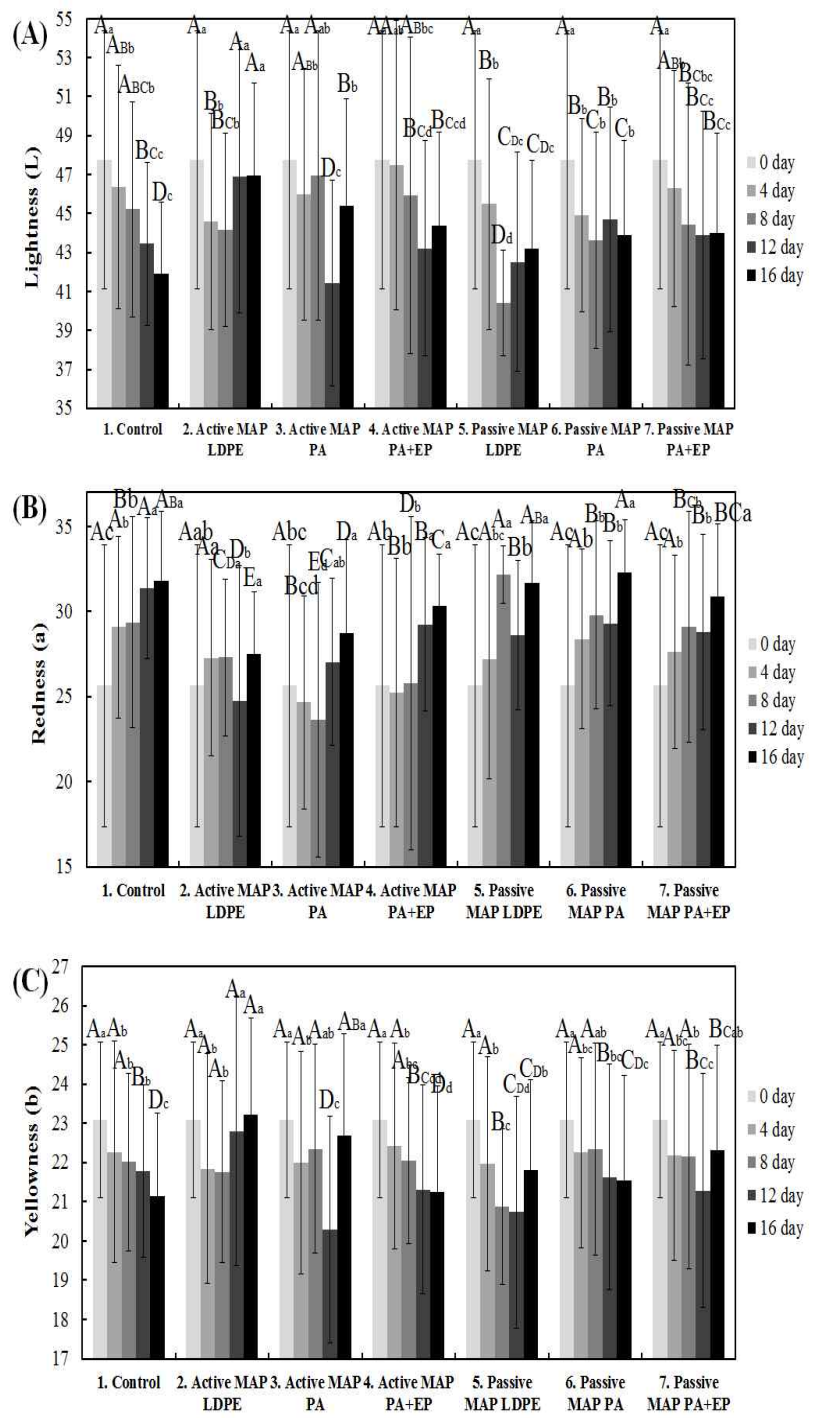

Fig. 8. Changes of lightness (A), redness (B) and yellowness (C) of strawberries by storage methods.

The bar graph means the mean value and the error bar means the standard deviation When the alphabetic capital letters in each graph are different, it means that there is a meaningful difference according to the kind of storage in the same storage day, and lower case letters are displayed differently when there is a difference in storage period within the same storage method. The determination of the difference was calculated by Duncan's multiple range test of significance level 0.05 .

24 시간 예냉 처리를 하는 등 시간이 지연되어 그 효과가 미미하였으리라 판단되었다. 이를 검증하고자 $70 \%$ 숙도로 선별된 딸기를 선별장에서 초기 $\mathrm{CO}_{2}$ 농도를 $20 \%$ 로 active $\mathrm{MA}$ 포장하여 13 일간 저장한 뒤 경도를 분석한 결과 대조구 $1.55 \mathrm{~N}$ 과 비교하여 $\mathrm{MAP}$ 처리구는 $1.67 \mathrm{~N}$ 으로 통계적으로 유의미하게 높게 유지되었다. 따라서 유통을 위해서는 초 기 $\mathrm{CO}_{2}$ 농도를 $20 \%$ 이상으로 하는 active $\mathrm{MAP}$ 를 적용하여 경도를 높게 유지하는 것이 유리하다고 판단된다.

MAP 저장에 따른 가용성 고형분 및 총산도 변화

딸기의 저장조건별 가용성 고형분 및 총산도의 변화는 
Fig. 9와 같다. 총산도의 경우 초기값이 상당히 높게 측정되 었다. 딸기 $2 \mathrm{~kg}$ 두 박스에서 딸기 5 개씩을 착즙한 16 개의 착즙액을 분석한 것을 감안할 때 이러한 급격한 차이는

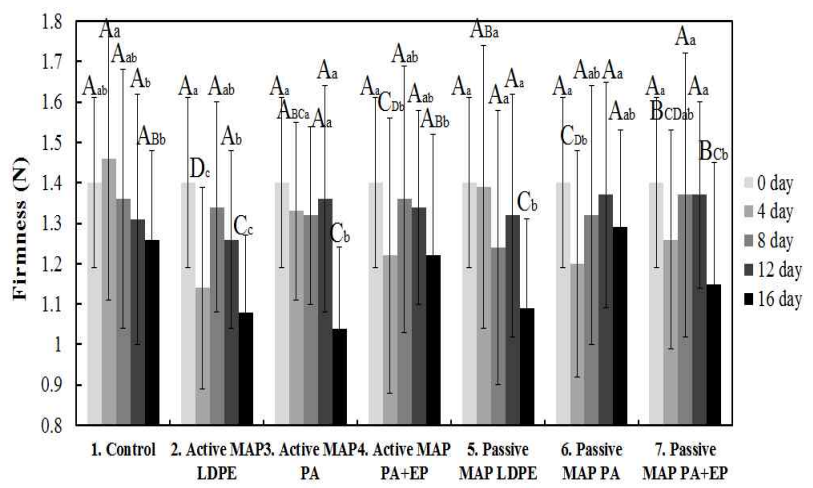

Fig. 9. Variation of firmness of strawberry according to storage period by storage method.

The bar graph means the mean value and the error bar means the standard deviation. When the alphabetic capital letters in each graph are different, it means that there is a meaningful difference according to the kind of storage in the same storage day, and lower case letters are displayed differently when there is a difference in storage period within the same storage method. The determination of the difference was calculated by Duncan's multiple range test of significance level 0.05 .
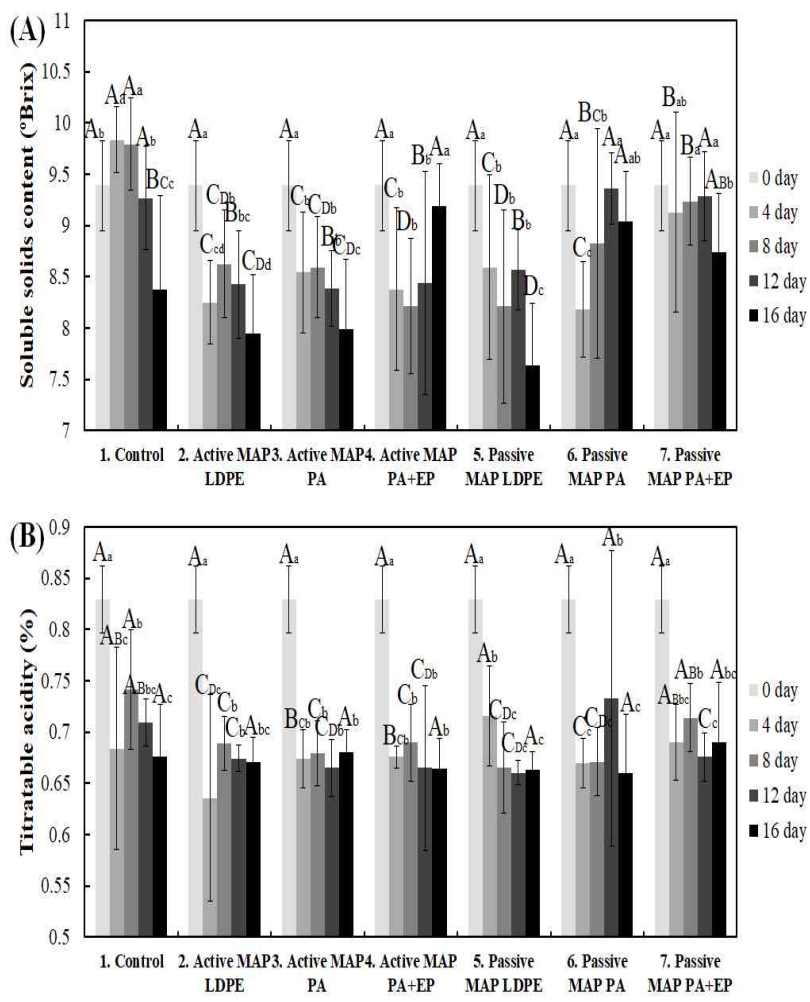

Fig. 10. Changes in soluble solids content (A) and titratable acidity (B) of strawberry during storage by storage method.

The bar graph means the mean value and the error bar means the standard deviation. When the alphabetic capital letters in each graph are different, it means that there is a meaningful difference according to the kind of storage in the same storage day, and lower case letters are displayed differently when there is a difference in storage period within the same storage method. The determination of the difference was calculated by Duncan's multiple range test of significance level 0.05 .
수작업 선별에서 선별자의 숙도 판단 차이 또는 실험 실수 에서 온 결과라 생각된다. 초기의 가용성 고형분과 이온수 가 유지된다고 가정할 때 감모율이 클 경우 더 높은 값을 가지게 될 것이라 생각할 수 있으며, 곰팡이가 증가할 경우 당분을 흡수 분해하여 급격하게 당도가 낮아질 것으로 예상 할 수 있다. 하지만 곰팡이가 발생한 것은 제외하고 착즙하 였기 때문에 측정값에서는 대조구의 가용성 고형분과 산도 가 MAP 처리군보다 약간 높게 나타났다. 이러한 결과는 Nielsen과 Leufven(8)의 결과에서도 무처리 저온저장의 가 용성 고형분과 산도가 MAP 처리구보다 높게 나타난 것과 일치한다.

\section{요 약}

본 연구에서는 수분투과도가 높은 PA 필름과 낮은 $\mathrm{LDPE}$ 필름을 이용한 $\mathrm{MAP}$ 의 감모율 및 곰팡이 발생률 차이, $\mathrm{EP}$ 훈 증 처리구와 미처리구의 곰팡이 발생률 차이를 분석하고자 하였고, MAP의 경우 active와 passive 기체조성을 하여 그 효과 차이를 알아보고자 하였다. PA 필름과 $\mathrm{LDPE}$ 필름 포장시 감모율의 차이는 통계적으로 차이가 없는 수준으로 LDPE가 낮았으나, LDPE 필름 내부에서 결로가 발생하여 수출 포장에서는 박스 젖음을 최소화 할 수 있는 PA 필름이 적정함을 확인하였다. 감모율이 높을 경우 당도와 산도가 높게 나타나기 때문에 MAP 대비 대조구에서 당도와 산도 가 약간 높게 측정되었다. 초기 $\mathrm{CO}_{2}$ 농도를 $20 \%$ 이상으로 active MAP 처리시 경도가 높게 유지되는 효과가 있으므로, passive MAP보다 유통에 유리할 것이라 판단된다. 딸기의 저장 중 발생한 곰팡이는 대부분 잿빛곰팡이병원균인 $B$. cinerea임을 배양을 통한 포자의 형상으로 확인하였으며, $\mathrm{MAP}$ 에서는 기체조성이 호기성인 곰팡이의 성장을 방해하 여 딸기 내부로만 균사가 자라는 것을 확인하였다. EP 처리 도 딸기 외부의 균사 성장을 억제할 뿐 내부의 성장을 막지 는 못하기 때문에, $\mathrm{EP}$ 처리 없이 $\mathrm{MA}$ 포장만 사용할 경우와 차이가 없음을 확인하였다. 대조구 및 $\mathrm{MA}$ 저장 딸기의 곰팡이 균사는 손자국에서 시작되는 것을 확인하였으며, 수확과 선별시 수확하는 딸기가 B. cinerea 포자에 오염되지 않도록 주의한다면, 곰팡이 발생을 더욱 억제할 수 있으리 라 예상된다. 이러한 결과에 비추어볼 때 감모율을 낮추고, 경도를 높게 유지하며, 결로와 곰팡이 발생도 억제할 수 있는 $\mathrm{PA}$ 필름을 이용한 active $\mathrm{MA}$ 가 딸기의 유통에서 최적 의 포장방법이라 판단된다.

\section{감사의 글}

본 연구는 2017년도 농촌진흥청 기관고유사업(과제번 
호: PJ01088701)의 지원에 의해 이루어진 것으로 감사드립 니다.

\section{References}

1. Nam MH, Kim HS, Lee WK, Gleason ML, Kim HG (2011) Control efficacy of gray mold on strawberry fruits by timing of chemical and microbial fungicide applications. Kor J Hort Sci Technol, 29, 151-155

2. Ahn SE, Lee AY, Wang MH, Hwang YS (2014) Increase of strawberry fruit shelf-life through preharvest spray of calcium-chitosan and post-harvest treatment with high pressure $\mathrm{CO}_{2}$. Kor J Hort Sci Technol, 32, 636-644

3. Smith RB, Skog LJ (1992) Postharvest carbon dioxide treatment enhances firmness of several cultivars of strawberry. Hort Science, 27, 420-421

4. Hwang YS, Min JH, Kim DY, Kim JG, Huber DJ (2012) Potential mechanisms associated with strawbery fruit firmness increases mediated by elevated $\mathrm{pCO}_{2}$. Hortic Environ Biotechnol, 53, 41-48

5. Kim JG, Choi JW, Park MH (2016) Effect of different days of postharvest treatment and $\mathrm{CO}_{2}$ concentrations on the quality of 'Seolhyang' strawberry during storage. Korean J Food Preserv, 23, 12-19

6. Park DS, Jeong CS (2015) Effect of $\mathrm{CO}_{2}$ and $\mathrm{ClO}_{2}$ gas pre-treatment for maintain shelf-life of summer strawberries. Kor J Hort Sci Technol, 33, 705-711

7. Bozkurt F, Tornuk F, Toker OS, Karasu S, Arici M, Durak MZ (2016) Effect of vaporized ethyl pyruvate as a novel preservation agent for control of postharvest quality and fungal damage of strawberry and cherry fruits. LWT-Food Sci Technol, 65, 1044-1049

8. Nielsen T, Leufven A (2008) The effect of modified atmosphere packaging on the quality of Honeoye and Korona strawberries. Food Chem, 107, 1053-1063

9. Park JW, Kim JS, Park SH, Choi DS, Choi SR, Kim YH, Lee SJ, Park CW, Lee JS (2016) Development of pallet-scale modified atmosphere packaging for 'Tabor' tomatoes. Korean J Food Preserv, 23, 614-622

10. Durak MZ, Churey JJ, Gates M, Sacks GL, Worobo RW (2012) Decontamination of green onions and baby spinach by vaporized ethyl pyruvate. J Food Prot, 75, 1012-1022

11. Tornuk F, Durak MZ (2015) A novel method for fresh-cut decontamination: efficiency of vaporized ethyl pyruvate in reducing Staphylococcus aureus and Escherichia coli O157:H7 from fresh parsley. J Food Process Preserv, 39, 1518-1524
12. Lee SH, Yoon DW, Jung JY, Lee KJ, Kim SJ, Lee EJ, Kang EH, Jung KH,Lee SY, Lee SY, Kim JH, Shin C, Shim JJ, In KH, Yoo SH, Kang KH (2006) The effects of ethyl pyruvate on lipopolysaccharide-induced acute lung injury. Tuberculosis and Respiratory Diseases, 61, 374-383

13. Kim JS, Park JW, Park SH, Choi DS, Choi SR, Kim YH, Lee SJ Park CW, Lee JS, Cho BK (2016) Study of pallet scale modified atmosphere packaging films for reducing water condensation. J Biosystems Eng, 41, 98-107

14. Geysen S, Verlinden BE, Conesa A, Nicolai BM (2005) Modelling respiration of strawberry (cv. 'Elsanta') as a function of temperature, carbon dioxide, low and superatmospheric oxygen concentration. Information and Technology for Sustainable Fruit and Vegetable Production FRUTIC 05, September 12-16, Montpellier, France

15. Mangaraj S, Goswami TK, Mahajan PV (2009) Applications of plastic films for modified atmosphere packaging of fruits and vegetables: a review. Food Eng Rev, 1, 133-158

16. Fonseca SC, Oliveira FAR, Brecht JK (2002) Modelling respiration rate of fresh fruits and vegetables for modified atmosphere packages: a review. J Food Eng, 52, 99-119

17. Belay ZA, Caleb OJ, Opara UL (2016) Modelling approaches for designing and evaluating the performance of modified atmosphere packaging (MAP) systems for fresh produce: a review. Food Packaging and Shelf life, $10,1-15$

18. Atkins P, de Paula J (2006) Physical Chemistry: thermodynamics, structure and change. $8^{\text {th }}$ edition, WH Freeman, Oxford, UK, p 756

19. Salvador ML, Jaime P, Oria R (2002) Modelling of $\mathrm{O}_{2}$ and $\mathrm{CO}_{2}$ exchange dynamics in modified atmosphere packaging of burlat cherries. J Food Sci, 67, 231-235

20. Gross KC, Wang CY, Saltveit M (2016) The Commercial Storage of Fruit, Vegetables, and Florist and Nursery Stocks. USDA Agriculture Handbook number 66, Agriculture Research Service, Washington DC, USA, $p$ 7-9

21. Pitt JI, Hocking AD (1997) Fungi and Food Spoilage $2^{\text {nd }}$ ed, Blackie academic and professional, London, UK, p 80-81

22. Kim DR, Jeon CW, Kwak YS (2015) Studies on Botrytis cinerea density in packing shed and gray mold incidence following storage-temperature in exported strawberry. Korean J Pestic Sci, 19, 295-300 